\title{
PENGARUH FRICTION DAN INFRA RED TERHADAP PENURUNAN NYERI AKIBAT LOW BACK PAIN PADA WANITA HAMIL DI RSKDIA FATIMAH MAKASSAR
}

\author{
Aco Tang \\ Jurusan Fisioterapi Politeknik Kesehatan Makassar \\ acotang45@gmail.com
}

\begin{abstract}
ABSTRAK
Hasil dari penelitian pada ibu hamil di berbagai daerah Indonesia mencapai 60- 80\% orang yang mengalami nyeri pinggang bawah pada kehamilannya (Mafikasari dan Kartikasari, 2015). Pada wanita hamil, tercatat 54,9\% di trimester 3 yang mengalami nyeri pinggang bawah dan sekitar $10 \%$ dari wanita dengan nyeri pinggang bawah kronis dimulai ketika hamil (Robertson, 2014). Nyeri pinggang bawah merupakan nyeri yang terjadi didaerah pinggang berikut pantat yang disebabkan oleh berbagai faktor penyebab seperti ketegangan otot, proyeksi organ dalam ataupun karena kerusakan organ tertentu yang disebabkan oleh berbagai faktor penyebab mulai dari faktor penyebab yang patologis seperti trauma sampai faktor penyebab yang fisiologis seperti kehamilan. Nyeri pinggang bawah dapat di tangani dengan intervensi fisioterapi seperti Infra Red dan Friction. Friction adalah suatu manipulasi atau massage ringan pada suatu titik tertentu pada jaringan dengan gerakan melingkar atau melintang dengan gerakan yang dibentuk tersebut tidak boleh bergeser dari permukaan kulit dan tetap bergerak bersamasama dengan menggunakan ujung ibu jari, jari atau tulang yang menonjol pada punggung jari tangan, yang ditujukan pada kapsul sendi, fascia dan ligament. Penelitian ini bersifat quasy eksperimen dengan dengan rancangan penelitian one group pre test dan post test design. Sampel yang diambil sebanyak 20 orang berumur antara 18-35 tahun. Penelitian ini menggunakan pengukuran nyeri sebelum dan setelah pemberian infra red dan friction selama 6 kali perlakuan. Data dianalisis melalui uji wilcoxon. Instrumen tes yang digunakan pada penelitian ini adalah VAS untuk mengukur nyeri akibat low back pain pada Wanita hamil di Rumah Sakit Khusus Daerah Ibu dan Anak (RSKDIA) Fatimah Makassar. Pemberian Friction dan Infra Red dapat menghasilkan penurunan nyeri pada penderita nyeri pinggang bawah sebesar 9,25 dengan nilai rata-rata pre test sebesar 55,25 dan nilai rata-rata post test sebesar 42,50. Disarankan kepada Fisioterapis agar menggunakan Friction dan infra red untuk mengurangi nyeri pinggang bawah pada wanita hamil trimester III.
\end{abstract}

Kata Kunci : Friction, Infra Red, nyeri, low back pain

\section{Pendahuluan}

Nyeri pinggang dapat disebabkan oleh berbagai kondisi. Kondisi-kondisi yang umumnya menyebabkan nyeri pinggang adalah strain lumbar, iritasi saraf, radiculopathy lumbar, gangguan pada tulang (stenosis spinal, spondylolisthesis), kondisikondisi sendi dan tulang (spondylosis), dan kondisi-kondisi tulang kongenital (spina bifida dan skoliosis). Diantara kondisi tersebut, telah diobservasi bahwa sekitar $90 \%$ pasien nyeri pinggang mengalami spondylosis lumbar. Sedangkan menurut (Robertson, 2014) nyeri pinggang dibagi atas 2 bagian yaitu mekanikal nyeri pinggang dan non-mekanikal nyeri pinggang. Mekanikal nyeri pinggang terdiri dari lumbar strain/sprain, spondylosis lumbal, piriformis syndrome, herniasi diskus, spinal stenosis, fraktur kompresi osteoporotik, spondylolisthesis, fraktur traumatik, dan penyakit kongenital (skoliosis). Diantara kondisi tersebut, spondylosis lumbal menduduki peringkat kedua dengan persentase
$10 \%$ dari mekanikal nyeri pinggang sedangkan lumbar strain/sprain memiliki persentase terbanyak yaitu $70 \%$ dari mekanikal nyeri pinggang.

Setiap manusia yang hidup sekitar 75 $80 \%$ pernah mengalami nyeri pinggang bawah (NPB). Lebih dari $80 \%$ pasien mengalami nyeri pinggang bawah berulang (Robertson, 2014). Hasil dari penelitian pada ibu hamil di berbagai daerah Indonesia mencapai 60- 80\% orang yang mengalami nyeri pinggang bawah pada kehamilannya (Mafikasari dan Kartikasari, 2015). Pada wanita hamil, tercatat $54,9 \%$ di trimester 3 yang mengalami nyeri pinggang bawah dan sekitar $10 \%$ dari wanita dengan nyeri pinggang bawah kronis dimulai ketika hamil (Robertson, 2014).

Nyeri pinggang bawah merupakan nyeri yang terjadi didaerah pinggang berikut pantat yang disebabkan oleh berbagai faktor penyebab seperti ketegangan otot, proyeksi organ dalam ataupun karena kerusakan organ 
tertentu. Kerusakan salah satu jaringan tertentu pada manusia dapat menimbulkan nyeri seperti : kerusakan tulang, persendian, ligamen dan otot. Kondisi ini bisa ditangani dengan menggunakan modalitas fisioterapi seperti

\section{Metode Penelitian}

Penelitian ini menggunaan metode Quasi Experiment, dengan rancangan penelitian one group pre test dan post test design yang dilaksanakan di RSKDIA Fatimah Makassar pada bulan September - Oktober 2017. Populasi penelitian ini adalah semua wanita hamil yang datang berobat ke poliklinik Fisioterapi sebanyak 31 orang. Sampel penelitian adalah pasien yang menderita nyeri pinggang bawah pada wanita hamil sebanyak 20 orang. Sampel diambil secara purposive sampling berdasarkan kriteria inklusif : penderita nyeri pinggang bawah akibat spasme otot, usia sampel 18 - 35 tahun, tidak kontra indikasi dengan pemberian friction dan infra red, dan bersedia menjadi responden.

Dilakukan dengan cara mencatat identitas sampel dan selanjutnya melakukan pengukuran nyeri sebelum dan sesudah friction dan infra red. Berdasarkan hal tersebut diatas peneliti tertarik untuk meneliti Pengaruh Friction dan Infra Red Terhadap Penurunan Nyeri Akibat Low Back Pain Pada Wanita Hamil Di RSKDIA Fatimah Makassar.

perlakuan. Pada tahap pelaksanaan setiap sampel diukur nyerinya. Data yang diperoleh dianalisis dengan menggunakan uji normalitas yang dilanjutkan dengan uji pengaruh. Pengolahan dan analisis data dengan menggunakan SPSS, kemudian disajikan dalam bentuk tabel dan narasi.

\section{Hasil dan Pembahasan}

Penelitian ini dilaksanakan di RSKDIA Fatimah Makassar selama 3 (tiga) bulan, mulai pada bulan September - Oktober 2017 dengan mengambil sampel sebanyak 20 ibu yang mengalami persalinan normal. Data diolah dan dianalisis disesuaikan dengan tujuan penelitian. Hasil analisis disajikan dalam bentuk tabel yang dilengkapi dengan penjelasan tabel sebagai berikut:

Tabel 1. Distribusi Kelompok Umur Wanita Hamil Trimester III di RSKDIA Fatimah Makassar Tahun 2017

\begin{tabular}{|c|c|c|}
\hline $\begin{array}{c}\text { Kelompok Umur } \\
\text { (Tahun) }\end{array}$ & Frekuensi & Persentase \\
\hline $18-23$ & 5 & 25,0 \\
$24-29$ & 8 & 40,0 \\
$30-35$ & 7 & 35,0 \\
\hline Jumlah & $\mathbf{2 0}$ & $\mathbf{1 0 0 , 0}$ \\
\hline
\end{tabular}

Sumber : Data Primer, 2017

Tabel 1 menunjukkan bahwa Kelompok Umur Wanita Hamil Trimester III di RSKDIA Pertiwi yang terbanyak adalah kelompok umur
24-29 tahun sebanyak 8 orang ( $40 \%$ ) sedangkan kelompok umur 18 - 23 sebanyak 5 orang $(25 \%)$.

Tabel 2. Distribusi Pekerjaan Wanita Hamil Trimester III di RSKDIA Fatimah Makassar Tahun 2017

\begin{tabular}{|c|c|c|}
\hline Pekerjaan & Frekuensi & Persentase \\
\hline PNS & 3 & 15,0 \\
\hline IRT & 15 & 75,0 \\
\hline Wiraswasta & 2 & 10,0 \\
\hline Jumlah & $\mathbf{2 0}$ & $\mathbf{1 0 0 , 0}$ \\
\hline
\end{tabular}

Sumber : Data Primer, 2017 
Tabel 2 menunjukkan bahwa pekerjaan yang terbanyak adalah IRT swbanyak 15 orang $(75,0 \%)$ dan yang paling sedikit wiraswasta 2 orang $(10,0 \%)$

Tabel 3. Distribusi Nilai VAS Pre test dan Post test

\begin{tabular}{|l|c|c|c|}
\hline Kondisi & Nilai Rerata & Standar Deviasi & $\mathrm{n}$ \\
\hline Pre test & 52,25 & 4,723 & 20 \\
\hline Post test & 42,50 & 3,035 & \\
\hline Selisih & 9,25 & 4,692 & \\
\hline
\end{tabular}

Tabel diatas memperlihatkan nilai rerata pre test yaitu 52,25 dan nilai rerata post test yaitu 42,50 dengan selisih nilai rerata adalah 9,25 Perubahan nilai rerata yang diperoleh menunjukkan adanya penurunan intensitas nyeri setelah diberikan Friction dan Infra Red.
Hal ini menunjukkan bahwa pemberian Friction dan Infra Red dapat menghasilkan penurunan nyeri pada penderita nyeri pinggang bawah pada wanita hamil trimester III, dengan rata-rata penurunan sebesar 9,25.

Tabel 4 Hasil Analisis Uji Wilcoxon

\begin{tabular}{|c|c|c|c|c|c|c|c|c|c|}
\hline \multirow{2}{*}{ Kondisi } & \multirow{2}{*}{$\mathrm{N}$} & \multirow{2}{*}{ Mean } & \multirow{2}{*}{ SD } & \multirow{2}{*}{$\begin{array}{l}\text { Beda } \\
\text { Rerata }\end{array}$} & \multicolumn{3}{|c|}{ Ranks } & \multirow{2}{*}{$\mathrm{Z}$} & \multirow[b]{2}{*}{$\mathrm{p}$} \\
\hline & & & & & - Ranks & + Ranks & Ties & & \\
\hline Pre test & 20 & 52,25 & 4,723 & \multirow{2}{*}{9,25} & \multirow{2}{*}{20} & \multirow[b]{2}{*}{0} & \multirow[b]{2}{*}{0} & \multirow[b]{2}{*}{$-3,968$} & \multirow[b]{2}{*}{0,000} \\
\hline Post test & 20 & 42,50 & 3,035 & & & & & & \\
\hline
\end{tabular}

Tabel diatas menunjukkan hasil Uji Wilcoxon yang terdiri dari nilai Ranks dan nilai Z. Berdasarkan nilai ranks, diperoleh angka 20 pada negatif ranks yang berarti bahwa semua responden mengalami penurunan intensitas nyeri setelah diberikan Friction dan Infra Red. Kemudian dilihat dari nilai $\mathrm{Z}$ diperoleh nilai sebesar $-3,968$ dengan nilai $\mathrm{p}=0,000<0,05$ yang berarti bahwa ada perbedaan yang bermakna setelah diberikan perlakuan dengan penurunan sebesar 0,000 . Hal ini menunjukkan bahwa pemberian Friction dan Infra Red dapat menghasilkan pengaruh yang bermakna terhadap penurunan nyeri pada penderita nyeri pinggang bawah pada Wanita Hamil trimester III.

Hasil penelitian yang terlihat pada tabel 3 menunjukkan bahwa pemberian Friction dan Infra Red dapat menghasilkan penurunan nyeri yang bermakna pada penderita nyeri pinggang bawah Wanita Hamil trimester III, dengan rata-rata penurunan nyeri sebesar 9,25. Nyeri pinggang bawah yang dengan pada Wanita Hamil disebabkan karena pembebanan di lumbal. Kondisi ini lama kelamaan akan menimbulkan spasme otot erector spine sehingga menghambat fungsional lumbal. Dengan demikian, problem nyeri dan spasme otot erector spine harus diatasi untuk mengembalikan fungsional lumbal.

Infra Red merupakan modalitas elektrotherapy yang menghasilkan energi elektromagnetik pada jaringan tubuh dengan penetrasi yang dangkal. Energi elektromagnetik yang diserap oleh jaringan menyebabkan efek thermal didalam jaringan. Begitu pula, pada otot erector spine yang sedikit superfisial mengalami efek thermal yang maksimal karena penetrasinya dapat mencapai otot tersebut. Efek thermal yang terjadi di otot dapat menyebabkan peningkatan sirkulasi dan metabolisme didalam otot serta peningkatan 
elastisitas dan ekstensibilitas pada myofibril otot (Prentice, 2003). Penurunan nyeri dan spasme otot dapat dicapai melalui mekanisme sirkulasi dan mekanisme gate control theory. Pada mekanisme sirkulasi, adanya peningkatan sirkulasi darah dapat mengangkut kembali zatzat iritan dan sisa metabolisme yang dapat meningkatkan konduktivitas nosisensorik (bradikinin, histamin, dan lain-lain), sehingga penurunan kadar zat-zat iritan tersebut dapat memperlambat konduktivitas nosisensorik yang akhirnya nyeri dan spasme akan berkurang. Sedangkan pada mekanisme gate control theory, adanya efek thermal yang nyaman memberikan efek sedatif pada ujung-ujung saraf sensorik sehingga aktivitas saraf sensorik tersebut dapat meredam aktivitas nosisensorik yang membawa impuls nyeri, dan akhirnya nyeri akan berkurang (Wadsworth, 1998).

Friction merupakan salahsatu bentuk massage dengan menggunakan ibu jari dan jarijari dengan penekanan dan gerakan transver atau sirkuler, dimana permukaan jari-jari tetap kontak dengan kulit. Friction dapat menyebabkan penurunan nyeri dengan segera, dimana pasien akan mengalami efek mati rasa selama friction dan setelah terapi menunjukkan adanya penurunan nyeri.

Berdasarkan analisis diatas, dengan menggunakan uji wilcoxon, diperoleh nilai $\mathrm{p}=$ $0,000<0,05$ yang berarti bahwa ada pengaruh yang bermakna friction terhadap penurunan intensitas nyeri. Hal ini dikarenakan Penurunan nyeri selama friction dan setelah friction disebabkan oleh modulasi impuls nosiseptive pada level medulla spinalis yang dikenal dengan "gate control theory". Proyeksi sentripetal kedalam cornu dorsalis medulla spinalis dari sistem reseptor nosiseptive akan di inhibisi oleh aktivitas mekanoreseptor yang terjadi secara bersamaan pada jaringan yang sama. Stimulasi yang selektif dari mekanoreseptor di hasilkan dari gerakan friction yang di ritmikal diatas area yang terganggu sehingga menutup pintu gerbang untuk nyeri.

Teknik deep friction seperti cross-fiber friction (transverse friction) bertujuan untuk mengurangi spasme atau tightnes otot, merusak atau memecah jaringan parut (scart tissue) yang adhesif, serta menyusun kembali serabut otot dan ligamen kedalam pola yang lebih biofungsional. Deep transverse friction merupakan bentuk massage yang paling potensial. Teknik ini dapat mencapai struktur jaringan yang dalam dari permukaan tubuh. Sumber nyeri biasanya berasal dari otot, tendon, ligamen, kapsul sendi atau facia, dimana dengan teknik friction ini dapat mencapai sumber nyeri tersebut. Disamping itu, menurut Cyriax transverse friction juga dapat menyebabkan peningkatan kerusakan metabolik provokasi nyeri seperti Lewis subtance. Metabolik ini, jika ada dalam konsentrasi yang sangat tinggi akan memprovokasi terjadinya ischemia dan nyeri. Cyriax juga menyatakan bahwa deep transverse friction pada area yang terganggu dapat menurunkan gangguan perifer jaringan saraf yang disertai efek analgesik lokal.

\section{Kesimpulan}

Berdasarkan tujuan dan hasil penelitian diatas, maka dapat disimpulkan dibawah ini sebagai berikut : Dilihat dari kelompok usia menunjukkan bahwa paling banyak responden yang berusia 24 - 29 tahun tahun adalah penderita nyeri pinggang bawah; Pemberian Friction dan Infra Red dapat menghasilkan penurunan nyeri pada penderita nyeri pinggang bawah sebesar 9,25 dengan nilai rata-rata pre test sebesar 55,25 dan nilai ratarata post test sebesar 42,50. Disarankan kepada fisioterapis di Rumah Sakit atau di lahan praktek agar menggunakan intervensi Friction dan Infra Red sebagai salah satu modalitas terpilih untuk kondisi nyeri pinggang bawah pada Wanita Hamil trimester III. Disarankan kepada fisioterapis di Rumah Sakit atau dilahan praktek agar memberikan edukasi kepada penderita nyeri pinggang bawah tentang kebiasaan mengggunakan postur yang baik saat bekerja atau beraktivitas. Disarankan kepada peneliti selanjutnya untuk meneliti dengan sampel yang lebih besar dan waktu yang lebih lama.

\section{DAFTAR PUSTAKA}

Apley, A. Graham dan Louis Solomon. 1995. Buku Ajar Ortopedi Dan Fraktur 
Sistem Apley, Edisi ke tujuh. Winya Medika: Jakarta

Arikunto, Suharsimi, 1997, Prosedur Penelitian Suatu Pendekatan Praktek, Rineka Cipta Jakarta.

A.N. De Wolf, J. MA. Mens, 1994, Pemeriksaan Alat Penggerak Tubuh, Jakarta

Anas Tamsuri, 2006, Konsep dan Penetalaksanaan Nyeri, Penerbit Buku Kedokteran EGC, Jakarta.

David J Maggie, 2006, Orthopedic Physical Assesment fourth edition, Sounders Elsevier, Toronto, Canada

Frances Tappan, 1988, Healing Massage Techniques, Appleton \& Lange, California.

Heru Purbo Kuntoro, Dkk, 1993, Sumber Fisis, Pusat Pendidikan Tenaga Kesehatan DEPKES RI, Jakarta.

Hasan M Iqbal, 2002, Pokok-Pokok Materi Metodologi Penelitian dan Aplikasinya, Ghalia Indonesia, Jakarta.

Hoppenfield , Stanley, Physical Examination of the Spine and Extremities, Appletion - century - New York.

J. Harjono, Retno Dumila, 2007, Perbedaan Pengaruh Perubahan Execise dalam Pencapaian Posisi Kepala yang Simeteri Akibat Torticolis, Jurnal fisioterapi Indonusa, Vol. VII No. 1.

Nicola J Petty and Ann P Moore, 2001, Neuromusculoskeletal and Assesment second edition, New York

Priguna Sidharta, 1985. Sakit Neuro Muskuloskeletal. PT.Dian Rakyat: Jakarta.

Randolph M. Kessler, Darlene Hertling, 1983, Management of Common Musculosceletal Disorder. Physical Therapy Principles and Methods, Harprer \& Row Publishers Inc. East Washington Square, Philadelphia.

Robertson, Jeanne. (2014). Pregnancy and Low Back Pain Physical Therapy Can Reduce Back and Pelvic Pain
During and After Pregnancy. Journal Of Orthopaedic \& Sports Physical Therapy.

Susan G. Salvo, 1999, Massage Therapy Principles and Practice, W. B. Sanders Company, Phyladelphia.

Susan J Garrison alih bahasa Anton Cahaya Widjaya, 2001, Dasar-dasar Terapi dan Rehabilitasi Fisik, Penerbit Hipokrates, Jakarta.

Soepeno, Bambang. 1997. Statistik Terapan. PT.Rineka Cipta: Jakarta

Soekidjo, Notoatmodjo. 1993. Metodologi Penelitian Kesehatan. PT. Rineka Cipta: Jakarta.

Sugiyono, 1997, Statistika dalam PeSnelitian, Alfabet, Bandung. 1999, Metode Penelitian Bisnis, CV Alfabeta, Bandung .

Sugiyono, 2006, Metode Penelitian Kualitatif, Kuantitatif dan $R \& D$, Penerbit Alfabeta Bandung.

Syafruddin Gaus, Manajemen Nyeri, Bagian Anestesiologi, Perawatan Intensif, dan Manajemen Nyeri, Fakultas Kedokteran Universitas Hasanuddin. Makassar.

Waluyo, Sugijanto, S. Indra Lesmana, 2004, Efektifitas Transverse Friction Terhadap Pengurangan Rasa Nyeri Pada Tennis Elbow, Majalah Fisioterapi Indonesia Vol 3 No 6.

Whitney W Lowe, 2009, Orthopedic Massage, Theory and Technique second edition, Elseiver.

William E Prentice, 2002, Therapeutic Modalities for Therapist, The McGraw-Hill Companies, 